\title{
Delayed Presentation of Blunt Neck Trauma Diagnosed with Bedside Ultrasonography
} Yatakbaşı Ultrason ile Tanı Konulan Künt Boyun Travmasının Geç Prezentasyonu

Serhat Akay', Huriye Akay', Nazif Erkan²

'Department of Emergency Medicine, İzmir Bozyaka Training and Research Hospital, İzmir, Turkey ${ }^{2}$ General Surgery Clinic, Izmir Bozyaka Training and Research Hospital, Izmir, Turkey

\section{ABSTRACT}

Introduction: Trauma of the salivary glands is rare, as penetrating traumas account for the majority of them. Few cases of blunt trauma of the submandibular glands are reported in the literature. Delayed presentation and airway compromise are the main concerns. Radiologic imaging is essential for diagnosis, where emergency physicians can diagnose with bedside ultrasonography.

Case Report: A 38-year-old male presented to our emergency department after discharge from another hospital following enlargement of the submandibular area. Bedside ultrasound showed enlargement of the left submandibular gland with a hypoechogenic line through the gland with preglandular fluid collection when compared to the right side. Computed tomography of the neck with intravenous contrast agent confirmed the diagnosis.

Conclusion: Isolated injury of the submandibular gland is rare, where the majority of reported cases is caused by MVCs. Minor appearing trauma can cause delayed presentations where the patient can re-present to the ED with more distinct findings. A bedside ultrasonography of the involved area can detect any abnormality of the affected gland and alert the physician for any possible airway compromise in the acute setting.

Keywords: Submandibular gland, trauma, neck injuries, bedside ultrasound

Received: 07.05.2014 Accepted: 09.06.2014

\section{ÖZET}

Giriş: Tükrük bezi travmaları nadirdir ve en sık nedeni penetran travmalardır. Literatürde künt submandibuler bez travma bildirimleri azdır. Geç prezentasyon ve havayolu obstruksiyonu önemlidir. Radyolojik görüntüleme önemlidir ve acil tıp hekimleri yatakbaşı ultrason ile tanı koyabilir.

Olgu Sunumu: 38 yaşında erkek hasta acil servisimize başka bir merkezden senkop sonrası submandibuler alanda şişlik nedeniyle tabruculuk sonrası başvurdu. Yatakbaşı ultrason sol submandibuler bezde sağa göre büyüme, bezde hipoekojenik çizgilenme ve periglandüler sıvı birikimi gösterdi. İntravenöz kontrastı boyun bilgisayar tomografisi tanıyı doğruladı.

Sonuç: İzole submandibuler tükrük bezi yaralanması nadirdir ve en sık nedeni motorlu taşıt kazalarıdır. Minor travmalar geç prezentasyona neden olabilir ve hastalar acil servise başka semptomlarla başvurabilirler. Etkilenen alanın yatakbaşı ultrason etkilenen bezdeki yaralanmayı saptayabilir ve akut durumda olası havayolu obstruksiyonu hakkında hekimi uyarabilir.

Anahtar Kelimeler: Submandibuler bez, travma, boyun travması, yatakbaşı ultrason

Geliş Tarihi: 07.05.2014 Kabul Tarihi: 09.06.2014

\section{Introduction}

Blunt traumas to the salivary glands are rare, and the exact incidence in blunt trauma involving the neck is unknown. Most cases of trauma to the submandibular glands are penetrating and stabbings, shootings, and iatrogenic procedures (1). The parotid gland is more susceptible to trauma, as the submandibular gland is protected by the mandibular arch. Few reports of blunt trauma to the submandibular glands are caused by motor vehicle collision (MVC), where patients present after a delay of time (2-5). 


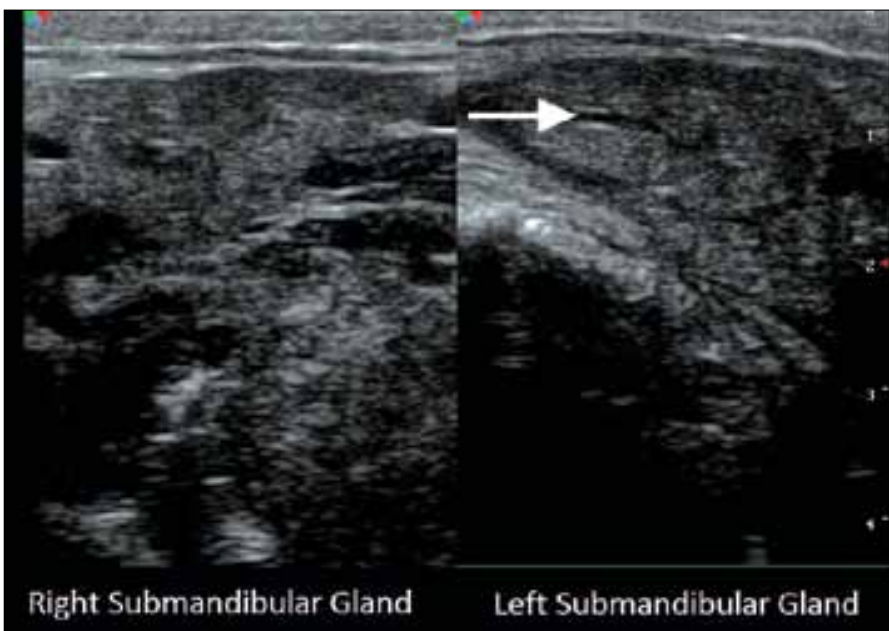

Figure 1. Bedside ultrasonography image of both submandibular glands, showing enlargement of the left submandibular gland with periglandular hypoechogenic-appearing fluid and laceration of the gland (arrow)

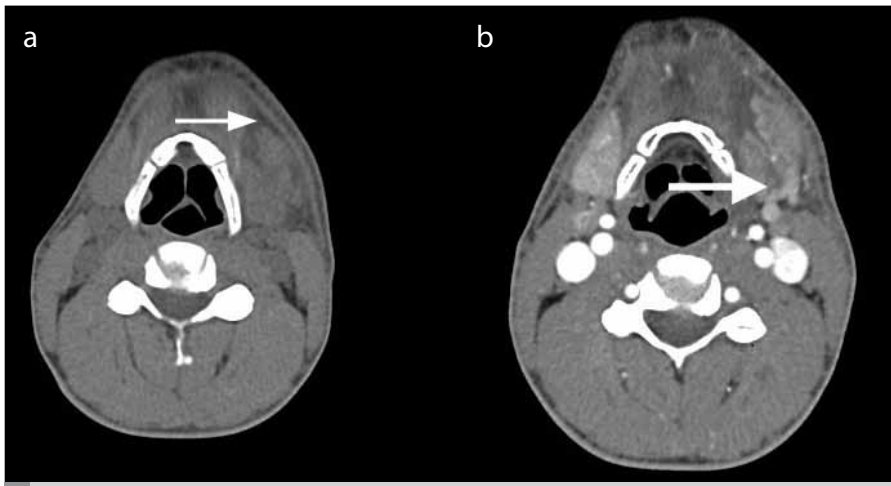

Figure 2. a, b. Noncontrast image of the submandibular fossa with enlargement of the left submandibular gland and periglandular fluid (arrow) (a), Contrast image of lacerated gland with fluid between lacerated glands (arrow) (b)

We report a delayed case of submandibular gland laceration that presented to the emergency department and was diagnosed with bedside ultrasonography and confirmed with computed tomography $(\mathrm{CT})$.

\section{Case Report}

A 38-year-old male patient presented to our emergency department (ED) after experiencing syncope after returning home from a night shift. He denied any chest pain or palpitations prior to syncope. He expressed that he hit the right side of his mandible before loss of consciousness. His wife, who witnessed the syncope, denied any contractions or post-ictal state. He regained consciousness after a few seconds. The patient denied any medical condition or prior drug use. He was followed in a local hospital ED, where his computed tomography showed a right temporal arachnoid cyst, and he was advised to be followed up by neurosurgery as an outpatient. After returning home and having lunch, he noticed a growing mass in his left submandibular fossa with mild tenderness. He denied any difficulty in swallowing or breathing.
Upon admission, his vitals were within the normal range. On physical examination, he had a visible tender mass without ecchymosis in the affected zone, while the remainder was normal. There were no signs of skin or mucosal penetration. His electrocardiogram showed normal sinus rhythm without any ischemic changes. Bedside ultrasonography with a 7.5 Mhz linear probe showed enlargement of the left submandibular gland with a hypoechogenic line through the gland with preglandular fluid collection when compared to the right side (Figure 1). Submandibular gland laceration was suspected. Pre- and postcontrast computed tomography (CT) of the neck showed increased volume of the left side of the submandibular fossa and low-attenuation lines of laceration with intraparenchymal hemorrhage of the fragmented right submandibular gland (Figure 2). Mandibular bone fracture was absent.

During his 4-hour stay in the ED, the patient did not experience any difficulty in breathing and tolerated food swallowing. The patient was consulted by an otolaryngologist and was decided to be followed up as an outpatient. Magnetic resonance of the neck reported similar findings to the $\mathrm{CT}$. The patient is currently being followed, and operation is planned if symptoms persist.

\section{Discussion}

Our case presents a distinct manifestation of blunt trauma, where prompt diagnosis can be made by bedside ultrasonography performed by emergency physicians.

Evaluation of a patient presenting after blunt trauma to the neck requires an organized approach involving a general approach to multi-trauma patient. The first concern should be the status of the airway, where delayed presentation of an extensive submandibular gland injury can compromise the airway and subsequent intubation can be required to maintain airway protection (5). Other injuries must be managed according to advanced trauma life support guidelines.

Examination of the patient involves a careful inspection of the oral cavity and surrounding mucosal and skin tissue. Palpation of the surrounding mandible can indicate fracture. Auscultation of the vascular structures in the neck is essential, as bruit can be a sign of pseudoaneurysm. Testing of the tongue's taste sensation is important, because lingual and hypoglossal nerves lie near the gland (5). Integrity of Wharton's duct is tested by massaging the gland and observing pooling.

The diagnosis is made radiographically. Although magnetic resonance is considered the gold standard imaging method for parenchymal neoplasms, it can be inaccurate in acute situations. Computed tomography is an accurate method for diagnosing, as it is readily available in the ED and visualizes the surrounding bony structures. Expected findings in CT include inflammation, edema, and fat stranding (2). Whether contrast medium use is needed for visualization is a matter of debate, as some authors suggest that hemorrhage may be hard to distinguish from the glandular 
parenchyma in postcontrast images (3). A contrasted CT scan was used to rule out any vascular involvement. A bedside ultrasonography of the involved area can readily diagnose a submandibular injury in an unstable patient, where airway protection and any conjunct injuries can risk the patient's status.

Bedside ultrasound use for soft tissue trauma in the ED for detection and removal of soft tissue foreign bodies has been studied in in vitro and in vivo studies extensively with high sensitivity and specificity (6-8). These studies showed that ultrasound had higher sensitivity in detecting radiolucent and radio-opaque foreign bodies when compared to radiographs and helped clinicians in removal. Detection of Achilles tendon rupture with ultrasound has 92\% accuracy (9). CT is commonly used for imaging of salivary glands after blunt or penetrating trauma, but radiation risk and expertise in the evaluation are crucial for a definite diagnosis. Few cases of blunt submandibular gland injuries that are reported in the literature used $\mathrm{C} T$ for diagnosis, but bedside ultrasound can provide rapid diagnosis in trauma patients $(3,10)$. Our case demonstrates the use of bedside ultrasound by emergency physicians for rapid diagnosis of a rare form of trauma.

Management of a submandibular gland injury starts with airway protection, where progressive swelling can lead to airway compromise in the acute setting or can delay up to 36 hours $(2,5)$. The required time of observation is uncertain, as some authors suggest that a prolonged time of observation is needed for patients with potential airway compromise (5). Beyond airway compromise, there is no agreement of the management of submandibular gland injury, due to its rarity. A short course of antibiotics and careful observation can be appropriate. There are no reported long-term complications.

\section{Conclusion}

Isolated injury of the submandibular gland is rare, where the majority of reported cases is caused by MVCs. Minor appearing trauma can cause delayed presentations, where the patient can re-present to the ED with more distinct findings. As in previous cases described in the literature, CT is the imaging modality of choice for diagnosis; a bedside ultrasonography of the involved area can detect any abnormality of the affected gland and alert the physician for any possible airway compromise in the acute setting.

Informed Consent: Written informed consent was obtained from patient who participated in this case.

Peer-review: Externally peer-reviewed.
Author Contributions: Concept - S.A.; Supervision - N.E.; Materials - H.A.; Analysis and/or Interpretation - N.E.; Literature Review - H.A., S.A.; Writer - S.A.; Critical Review - H.A., N.E.

Conflict of Interest: The authors declared no conflict of interest.

Financial Disclosure: The authors declared that this study has received no financial support.

Hasta Onamı: Yazılı hasta onamı bu olguya katılan hastadan alınmıştır.

Hakem Değerlendirmesi: Dış bağımsız.

Yazar Katkıları: Fikir - S.A.; Denetleme - N.E.; Malzemeler - H.A.; Veri toplanması ve/veya işlemesi - N.E.; Literatür taraması - H.A., S.A.; Yazıyı yazan - S.A.; Eleştirel İnceleme - H.A., N.E.

Çıkar Çatışması: Yazarlar çıkar çatışması bildirmemişlerdir.

Finansal Destek: Yazarlar bu çalışma için finansal destek almadıklarını beyan etmişlerdir.

\section{References}

1. Nahlieli O, Droma EB, Eliav E, Zaguri A, Shacham R, Bar T.. Salivary gland injury subsequent to implant surgery. Int J Oral Maxillofac Implants 2008; 23: 556-60

2. Roebker JJ, Hall LC, Lukin RR. Fractured submandibular gland: CT findings. J Comput Assist Tomogr 1991; 15: 1068-9. [CrossRef]

3. Tonerini M, Fratini L, Grassi L, Ravenna V, Tozzini A, Trincavelli F, et al. Blunt submandibular gland trauma: acute CT findings. Emerg Radiol 2002; 9: 116-8. [CrossRef]

4. Boyd BC, Dattilo DJ, Liberto FJ. An unusual supplemental vehicle restraint-induced injury: report of case and review of literature. J Oral Maxillofac Surg 2002; 60: 1062. [CrossRef]

5. Harbison Jm, Page MP. Submandibular gland injury and delayed airway compromise caused by a seat belt. Am J Otolaryngol 2010; 31: 209-11. [CrossRef]

6. Crystal CS, Masneri DA, Hellums JS, Kaylor DW, Young SE, Miller MA, et al. Bedside ultrasound for the detection of soft tissue foreign bodies: a cadaveric study. J Emerg Med 2009; 36: 377-80. [CrossRef]

7. Turkcuer I, Atilla R, Topacoglu H, Yanturali S, Kiyan S, Kabakci N, et al. Do we really need plain and soft-tissue radiographies to detect radiolucent foreign bodies in the ED? Am J Emerg Med 2006; 24: 763-8. [CrossRef]

8. Callegari L, Leonardi A, Bini A, Sabato C, Nicotera P, Spano E., et al. Ultrasound-guided removal of foreign bodies: personal experience. Eur Radiol 2009; 19: 1273-9. [CrossRef]

9. Hartgerink P, Fessell DP, Jacobson JA, van Holsbeeck MT. Full- versus partial-thickness Achilles tendon tears: sonographic accuracy and characterizationin 26 cases with surgical correlation. Radiology 2001; 220: 406-12. [CrossRef]

10. Roebker JJ, Hall LC, Lukin RR. Fractured submandibular gland: CT findings. J Comput Assist Tomogr 1991; 15: 1068-9. [CrossRef] 